\title{
Improvement of the Evaluation of Quality of the Integrative Intellectual Resource of the Higher Educational Establishment
}

\author{
Klaudia Ivanovna Safonova ${ }^{1} \&$ Stanislav Valerievich Podolskii ${ }^{1}$ \\ ${ }^{1}$ Department of economy and management on the enterprise of the Far-Eastern Federal University, Vladivostok, \\ Russia \\ Correspondence: Podolskiy Stanislav Valerievich, Okeanskiy prospect, 125, kv. 121, Vladivostok, Primorskiy \\ krai, 690002, Russia. Tel: 89-24-230-8819. E-mail: clame1979@mail.ru
}

Received: November 15, 2015 Accepted: January 20, 2014 Online Published: April 30, 2015

doi:10.5539/ass.v11n12p112 URL: http://dx.doi.org/10.5539/ass.v11n12p112

\begin{abstract}
The article deals with the analysis of problems and ways of evaluation improvement of the integrative intellectual resource of the modern higher educational establishment. The recommendations on the improvement of indicators aggregate, characterizing the quality of students and teaching staff, were developed and substantiated. The integrative indicators of the intellectual resource evaluation of the higher educational establishment and model of their calculation were offered. It is concluded that it is necessary to improve both organization and estimation of providing the educational services, including the intellectual resource state of the higher educational establishment, as its most important constituent. The offered methods provide evaluation not only of integral indicator of the intellectual resource state, but also of local indicators, i.e. different aspects professor-teaching staff competence, its ability to arrange contact with the audience, ability of students to perceive material, their activity in the process of study and etc. The methods are applied for estimation of the intellectual resource of the higher educational establishments of different countries, as at all peculiarities of national systems of higher professional education, it faces the similar problems.
\end{abstract}

Keywords: education, educational service, intellectual resource of the higher educational establishments, quality of education, quality of students, integrative indicator of quality evaluation

\section{Introduction}

The development of productive forces of any country is the key factor of economic stability and competitiveness of the state. The main constituent of the productive forces is a human factor, as only he possesses creative ability and is able to provide efficiency of the use of other elements of resource potential of the country. The quality of labour force and its effectiveness depends on the level of education, both school and higher one. The last is increasingly determined by the intellectual-personality potential of both students and teaching staff.

The purposeful management of the development of this potential, as a condition of increase of education efficiency is impossible without objective estimation of its level.

\section{Method}

It should be noted that today higher education in Russia is very accessible: it is marked, that $88 \%$ school-graduates enter into higher educational establishments (Livanov \& Volkov, 2012). However, high quantitative indicators not always mean the proper quality of providing the educational service and even can enter into contradiction with it. Therefore, it is very important to evaluate factors, affecting the quality, and purposefully influence on them. As in the case of the production process of every product or service, here the quality is under effect of great number of external and internal environment characteristics. However, first of all, this is the state of resources used in educational process. It is impossible to belittle the value of material-technical, informational, and financial provision, without which the process of providing the educational service is impossible. However, as well as in any production, a human factor plays the primary role as all material, financial and other resources are set in motion and used by workers - in this case, by the teaching staff of higher educational establishments. At the ineffective use of these resources, the low competence of teachers, weak ability to pass knowledge, abilities and skills etc. to the students, the result of educational process cannot be satisfactory. 
Unlike the ordinary production process, in providing the educational service the human factor plays special part and has brightly expressed specificity. If to examine the production of material products, then its result is determined by the labour productivity and competence of workers, and also the level of guidance. Users can play the indirect role only, affecting on the characteristics and quality of the goods by means of demand level, and the single condition of product obtainment is its payment. In educational process the student is a consumer. However, it is impossible to achieve the necessary result, if the student does not take part in this process of direct, active and creative participation. Thus, here the consumer simultaneously is a co-producer, i.e. so important constituent of human resource, as well as professor-teaching staff (PTS). In addition, it is necessary to mark the role of educational-auxiliary staff (EAS), which, although directly, does not form an educational product, i.e. does not take direct participation in teaching, but create the necessary conditions for the normal flow of educational process. Therefore, in our opinion, it is possible to speak about the integrative intellectual resource of higher educational establishment (Podolskii, 2010; Safonova \& Podolskii, 2012). Such resource is the aggregate of initial intellectual-personal potentials of students, professor-teaching staff (PTS) and educational-auxiliary staff (EAS) of higher educational establishments.

The decisive role, which quality of integrative intellectual resource plays in ensuring the required effectiveness for providing the educational service of higher educational establishment puts the question about necessity of its comprehensive estimation, above all things, concerning the students and PTS.

The problem of estimation and raising the level of qualification of the specialists' training, owning the critical and creative thought, able to work out concrete problems, to adjust communications, is not specific for the concrete country, but have the international character. The general nature of problem is confirmed by the results of research conducted by one of the authoritative universities of the world level - Stanford University of the USA.

The results of study showed that:

- The modern criteria of estimation of higher professional education quality in the USA show ability of the students to pass testing successfully, but insufficiently reflect the possession of the problem and critical thought;

- The changing character of work and society requires aiming of the students, first of all, on successful decision of the concrete problems, and also on ability to adjust communications, and effective business intercourse;

- Deep transformation is required, both educational programmes and indicators of the estimation of study results that is a task of state managerial bodies for education all over the world (Criteria for Higher-Quality Assessment, 2013).

The decision of this problem is impossible without creation of the new educational standards, which must include the requirements claimed to intellectual-personal potential of students and teaching staff, as to one of the conditions of mastering the educational material and further successful career.

However, only determination of the requirements to potential of teaching staff and students are not enough for the real growth of education quality. The purposeful perspective and current management of this potential formation is needed. The last one is impossible without analysis over the existence of the level, objective and qualitative estimation.

The authors of research, conducted by the Stanford University also point out on the necessity of formation of the requirement to students' quality and their estimation:

- The skills of higher level, providing the practical application of results of study must be evaluated;

- The abilities of students to communication, planning, modelling, and study must be evaluated, at that in such a way as if these capabilities applied already directly in the practice, but on in the process of education.

- Estimations must carry an international character and be rigid;

- Estimations must be built in such a way that the student could show knowledge, skills and habits, received namely in the process of study, but not reflecting his life experience, accumulated outside the educational establishments (Criteria for Higher-Quality Assessment, 2013).

- Estimations must be accurate and impartial (Criteria for Higher-Quality Assessment, 2013).

Actuality of the examined problem, in particular, for the Russian higher education, is confirmed by both data of official statistics from all higher educational establishments, and results of the conducted researches. On the one part, there is insufficiently high quality of knowledge, skills and habits of the school-leavers, who enter into the higher educational establishments. First of all, it should be noted that the problems with the state of health of 
school-leavers that in itself creates obstacles for the effective mastering of educational material and its further application in practice. According to the results of study, conducted by Rappoport I.K. (2011), only 1-2\% of senior pupils can be considered absolutely healthy, $68-70 \%$ suffer with chronic disease, and $28-30 \%$ with functional disorders. $80 \%$ of teenagers have medical contraindications to studying these or other specialties.

The indications of advancements of senior pupils are also insufficiently high. The results of passing USE serve the illustration of the insufficient level of advancement. For example, according to the results of passing USE in Primorsk Territory in 2011,3.5\% of the school-leavers of secondary schools didn't receive certificates (Results of USE were summarized in Vladivostok, 2011). The average points of school-leavers of Primorsk Territory in 2011 detected only insignificant positive dynamics in comparison to 2010: 55.13 points compared to 52.47 in the Russian language; 39.19 points compared to 35.86 in mathematics; 54.25 points compared to 53.1 in natural science and etc. (Results of USE were summarized in Primor'e, 2011). It tells about very low level of the required knowledge, skills and habits of the considerable part of school-leavers.

Moreover, according to the results of study, conducted by 11-form senior pupils under the management of Avraamova N. A. (2009), interests, depositions and abilities don't coincide with the chosen profile of the speciality in $40 \%$ and $33.4 \%$ of 9-form pupils of two forms chosen for conduction of the study, and in $41.2 \%$, $25.9 \%$ and $21.4 \%$ in 10 -form pupils of three studied forms, and in $14 \%$ of 11 -form pupils. At the same time in $22 \%$ of 11-form pupils, the dispositions, abilities and chosen profile of the speciality coincide only partially. Consequently, in enough considerable part of the potential school-leavers (although this share is a little reduced upon the extent of approaching to the school leaving), misfit of the speciality is observed, which they desire to study and real abilities to learning. At such misfit the achievement of the high level of quality of the educational services and results in problematic.

From 10 to $20 \%$ of school leavers of the Russian higher educational establishments at the selection of speciality generally are not guided by the economic motives, and less than a half of school-leaver (33-43\%) are informed about the perspectives of labour employment on the selected speciality (Mogilchak, 2009). Consequently, the majority of school-leavers have no distinct representation about future professional activity and, thus, about conditions, which should be applied in order to become the good specialist.

Thus, the psychophysical characteristics of school-leavers and characteristics of their learning capability, and acquired educational level, and level of motivation are not sufficient for provision of the active participation of students in the process of educational services provision.

On the one part, the characteristics of state are not satisfactory and, on the other part, the other constituent of integrative intellectual resource - professor-teaching staff (PTS). First of all, it is necessary to mark the problems of the qualitative content of the teachers. In Russia the share of PTS aged below forty years makes totally $35 \%$ (Osovetskaya, 2012). The teachers aged from $40-49$ years old $-20.6 \%, 50-59$ years old $-23 \%$, older 60 years old $-21.3 \%$, average years of PTS makes 45-46 years (Nevinskii, 2010; Osovetskaya, 2012). The average age of doctors and candidates of sciences in the Russian state higher educational establishments is higher respectively, 61 and 53 years old (Nevinskii, 2010). In the higher educational establishment of Primorsk Territory the share of PTS aged from 30 years old for 2009/10 makes $14 \%, 30-39$ years old $-21.5 \%$, 40-49 years old $-17.3 \%$, 50-59 years old $-23.4 \%$, 60-65 years old $-11.8 \%$, 66 years old and older $-12 \%$ (Professional education in Primorsk, 2010).

Thus, the reduction both the total number of regular PTS and number of doctors of sciences is observed. For the whole examined period the total number of regular PTS in the higher educational establishments of Primorsk Territory reduced for $15.6 \%$, including the number of doctors of sciences - for $2.23 \%$. Some growth was observed only according to the number of candidates of sciences (Zimniaya, 2008; Safonova \& Chmyr', 2009).

The share of doctors and candidates of sciences for the examined period increased, however, it happened, mainly, as a result of reduction of the total number of PTS. The share of doctors of sciences in the higher educational establishments of Primorsk Territory remains very low (as it made $9.4 \%$ in 2008/2009 as opposed to $8.11 \%$ in 2005/2006 and as opposed $12.33 \%$ wholly according to the Russian Federation for 2010 without taking in account external part-timers) (Safonova \& Chmyr', 2009). It tells about relative insufficient qualification of the teaching staff of the higher educational establishments that also prevents to the high level of organization of the provision of educational services.

Also the fact that the per cent of steady behaviour among external part-timers turns out to be higher than the analogous indicator according to the teaching staff ( $68.74 \%$ as opposed to $64.45 \%)$ draws attention. Moreover, this excess is achieved at the expense of substantially big share of doctors of sciences (accordingly, $22.7 \%$ as opposed to $12.33 \%$ ). Thus, according to the level of qualification the external part-timers turn out to be higher 
that the basic PTS of higher educational establishments that also don't tell in favour of the qualification of teaching staff.

It is also important to mark that the typical number of students of the Russian higher educational establishment makes from 6 to 7 ths. students, or nearly 10 students that falls for 1 teacher. This is very big loading counting on 1 unit of PTS, so it is appropriate to draw bigger number of highly-qualified teachers in the staff (including at the expense of external part-timers).

The negative effect on the qualitative characteristics of PTS is made by the factors of insufficient payment of the teachers' labour, reducing the stimuli to obtainment of the academic degree, insufficiently high level of the scientific-research activity of higher educational establishments and training of the scientific staff.

The detected lacks of quality both the student contingent, and teaching staff of the higher educational establishments of the Russian Federation, speak about necessity of conduction of deeper qualitative analysis. Meanwhile, the quality of estimation of the students and teaching staff of the Russian higher educational establishments presently bear one-sided and predominantly qualitative character. Thus, the active methods of state accreditation of the higher educational establishments of Russia use such evaluative indicators as the number of students' contingent, share of students, who mastered the discipline as the basic part of cycle of the federal state educational standard - FSES (no less than $60 \%$ ), the share of persons with academic degrees and titles in the regularly PTS, the per cent of teachers who passed the skill extension courses. The estimation on the level of higher educational establishments is executed in the same direction. The emphasis is made on such characteristics as dynamics and structure of admission into the higher educational establishments on the forms of study, budget and contractual financing, competition selection and non-competitive admission, indicators of the intermediary and summary advancement, including the pass of intermediary exam and protection of GQW, indicators of the department staff, including the total number of workers of each department, specific rile of the doctors of sciences, professors and persons with academic degree and title and etc.

Not denying absolute meaningfulness of the resulted descriptions for estimation of the state of student contingent and teaching staff of higher educational establishments, it should be noted that they cannot in a sufficient degree reflect neither quality of the educational process, nor effectiveness of providing the educational services. It is impossible to estimate by them the real level of knowledge's, abilities and skills of a student and possibility of their practical application in professional activity. The effect of service for students is the set of the benefits, obtained by them, for example, certain position occupation at the labour market, material position, social status and etc. In order to attain such effect, it is necessary to estimate, how much the students are satisfied with providing the educational services, what are their requirements and expectations, what shortages, from their point of view, are inherent to the educational process, what weak sides they see as their professional training.

So the necessity of study conduction by the users by means of survey conduction in the form of questionnaire is evident. We conducted the study on the example of four higher educational establishment of Primorsk Territory of the Russian Federation, leaders on the market of educational services - FESU, FESTU, VSUES and TSEU. 300 respondents were asked. The issues concerned the criteria of qualitative educational service, on the students' opinion, the characteristics of the quality of education, motives of selection of the higher educational establishment and speciality, advancement, factors, affecting on the training quality, including qualification and characteristics of teachers, as well as evident usefulness of the service and level of its satisfaction. The respondents were also asked to indicate on their own discretion the weak parts on their training, as future specialists. According to the results of conducted study the following conclusions were made:

- The average advancement is close to the good one, and desire to become highly-qualified specialist serve the predominating factor of such progress;

- The majority of respondents consider obtainment of skills and professional experience for the labour employment and career to be the motivation factor at the choice of higher educational establishment and training direction, and at the same time the prestige of fundamental and general educational knowledge is low;

- The absence of probations and probation programmes, which would be connected directly with the professional practice, are the basic shortages of the educational system of higher educational establishments;

- The usefulness of educational service, mainly, is recognized as high one, but the shortages are also marked;

- The presence of highly-skilled teachers and then the material-technical basis (library, laboratory and etc.) are considered to be the first priority characteristics of the qualitative educational service is recognized;

- The students evaluate skills more in teachers, then - the ability to draw students, and theoretical knowledge are evaluated less; 
- As the basic weak side as future specialists the respondents consider the predominance of theoretical knowledge over practical ones, ignorance of business-processes and business-environment, incompliance of content of the educational programmes to the labour market demands;

- Generally, the students give high value to satisfaction with the quality of education, but it is necessary to take into account the insufficient substantiation of putting estimates.

According to the results of study it is necessary to separate the basic negative qualitative characteristics of the educational services of higher educational establishments:

- The students one-sidedly estimate the quality of educational services, underestimate the fundamental constituent of education and its connection with the level of practical skills; the factors of reduction of the fundamental education level, the low labour payment in the scientific-educational sphere, insufficient level of education of many managers of enterprises and organizations affect this regularity;

- The students mark weak compliance of the educational programmes of labour market demands and insufficiency of obtained practical skills and probations, connecting education with professional practice, what was influenced, on the one part, by the destruction of earlier existed connections between enterprises and higher educational establishments and slow tempos of their reproduction, and on the other part - slow tempos of reconstruction of the very system of higher professional education in accordance with the new state of the external environment;

- Educational process is weakly oriented on the competent approach and implementation of innovations, that is, first of all, connected with the relative novelty of this approach, and secondly, with insufficient high level of the scientific-research and innovative activity of the higher educational establishments;

- The students still didn't felt necessity in the new properties of the educational services or pay a little attention to them that, first of all, tells about insufficient expressiveness of these properties, and secondly, about relative low level of students' motivation, and level of awareness of the aims of study.

The system of providing the educational services does not provide expression completeness of the necessary properties to the end, such as an active role of the user, aimed on forming competences and etc. The results of the conducted research also show that the level of organization and real results of providing the educational services need the increase, and for this purpose perfection of their estimation is required, in particular.

It is impossible to substantiate and develop measures on the complex advancement of the intellectual resource of the higher educational establishment, relying only on such characteristics, as a quantity of students and teachers, share of persons with academic degrees, indicators of progress and etc. However, from other side, the high-quality characteristics, such as a competence of teachers, degree of mastering the knowledge's, abilities and skills, desire of students to be taught and similar to them, expressed in the verbal form ("satisfactorily", "good", "insufficient" and etc.), also cannot serve as a basis for comprehensive and objective estimation. It is necessary to formalize and express these characteristics, as far as it is possible, through the concrete indicators. There appear the necessity of substantiation, development and calculation of the local indicators, characterizing the students and teachers of higher educational establishments. Moreover, the total and integral indicator, which characterizes the integrative intellectual resource in the aggregate of its qualities, is necessary. The local indicators of quality must be put in the basis of such calculation.

All above-mentioned conditions the necessity of the improved methodology development for estimation of the intellectual resource quality that must respond to the number of requirements:

- Thorough characteristic: it must cover all basic characteristics of the intellectual resource, so it is necessary to use both quantitative and qualitative indicators;

- Commensurability of indicators: all used indicators must be conducted to the single scale of estimation;

- Integral nature: the total and integral indicator can be calculated on the basis of local indicators;

- The complex usage of the information sources: in the process of estimation both official data of state statistics, higher educational establishments, and data detected in the course of questionnaires of the interesting parties must be used.

Based upon the calculation of these requirements the aggregate of indicators, characterizing the integral intellectual resource of higher educational establishments and model of their calculation is offered (table 1).

Thus, the integral indicator of intellectual resource estimation of the higher educational establishment is offered to be calculated as average arithmetic three local coefficients: 
- students' qualities $\left(\mathrm{Q}_{\mathrm{st}}\right)$

- PTS qualities $\left(\mathrm{Q}_{\mathrm{pts}}\right)$

- quality of interaction of teachers with students in the process of study ( $\left.\mathrm{Q}_{\text {int }}\right)$.

Table 1. Model of calculation of the integral indicators of intellectual resource estimation of the higher educational establishment

\begin{tabular}{|c|c|c|}
\hline $\begin{array}{l}\text { Integral indicator of quality estimation of } \\
\text { the integrative intellectual resource }\left(\mathrm{Q}_{\text {iir }}\right)\end{array}$ & Local indicators & $\begin{array}{c}\text { Calculation way of indicators } \\
\mathrm{Q}_{\text {iir }}=\left(\mathrm{Q}_{\mathrm{st}}+\mathrm{Q}_{\mathrm{pts}}+\mathrm{Q}_{\text {int }}\right) / 3 \\
\end{array}$ \\
\hline \multirow{11}{*}{1 Coefficient of students' quality $\left(\mathrm{Q}_{\mathrm{st}}\right)$} & & $\begin{aligned} Q_{\mathrm{st}} & =\left(\mathrm{Q}_{\mathrm{cm}}+\mathrm{Q}_{\mathrm{sm}}+\mathrm{Q}_{\mathrm{lrn}}+\mathrm{Q}_{\mathrm{d}}+\mathrm{Q}_{\mathrm{pa}}+\mathrm{Q}_{\mathrm{lc}}\right. \\
& \left.+\mathrm{Q}_{\mathrm{ipv}}+\mathrm{Q}_{\mathrm{srws}}+\mathrm{Q}_{\mathrm{advn}}+\mathrm{Q}_{\mathrm{aeo}}\right) / 10\end{aligned}$ \\
\hline & $\begin{array}{l}\text { 1.1 Coefficient of motivation of higher } \\
\text { educational establishment choice by the } \\
\text { school-leavers }\left(\mathrm{Q}_{\mathrm{cm}}\right)\end{array}$ & $\begin{array}{c}\text { (students' estimation }+ \text { PTS estimation) } \\
/ 2\end{array}$ \\
\hline & $\begin{array}{l}1.2 \text { Coefficient of motivation of speciality } \\
\text { choice by the school-leavers }\left(\mathrm{Q}_{\mathrm{sm}}\right)\end{array}$ & $\begin{array}{c}\text { (students' estimation }+ \text { PTS estimation) } \\
/ 2\end{array}$ \\
\hline & $\begin{array}{l}1.3 \text { Coefficient of students' ability to learn } \\
\text { material }\left(\mathrm{Q}_{\mathrm{Irn}}\right)\end{array}$ & $\begin{array}{c}\text { (students' estimation }+ \text { PTS estimation) } \\
/ 2\end{array}$ \\
\hline & $\begin{array}{l}\text { 1.4 Coefficient of student's desire to } \\
\text { obtain knowledge, skills and habits }\left(\mathrm{Q}_{\mathrm{d}}\right)\end{array}$ & $\begin{array}{c}\text { (students' estimation + PTS estimation) } \\
1 / 2\end{array}$ \\
\hline & $\begin{array}{l}1.5 \text { Coefficient of students' ability to } \\
\text { perception of the knowledge transmitted } \\
\left(\mathrm{Q}_{\mathrm{pa}}\right)\end{array}$ & $\begin{array}{c}\text { (students' estimation + PTS estimation) } \\
1 / 2\end{array}$ \\
\hline & $\begin{array}{l}1.6 \text { Coefficient of completeness of } \\
\text { educational material learning }\left(\mathrm{Q}_{\mathrm{lc}}\right)\end{array}$ & $\begin{array}{c}\text { (students' estimation + PTS estimation) } \\
1 / 2\end{array}$ \\
\hline & $\begin{array}{l}\text { 1.7 Coefficient of students' disposition to } \\
\text { assertion of the independent point of view } \\
\left(Q_{\text {ipv }}\right)\end{array}$ & $\begin{array}{c}\text { (students' estimation }+ \text { PTS estimation) } \\
1 / 2\end{array}$ \\
\hline & $\begin{array}{l}1.8 \text { Coefficient of students' disposition to } \\
\text { the scientific-research work }\left(\mathrm{Q}_{\text {srws }}\right)\end{array}$ & $\begin{array}{c}\text { (students' estimation }+ \text { PTS estimation) } \\
/ 2\end{array}$ \\
\hline & 1.9 Coefficient of students' advancement & (students' estimation + PTS estimation) \\
\hline & $\begin{array}{l}\left(Q_{a d v n}\right) \\
1.10 \text { Coefficient of advancement } \\
\text { estimation objectivity }\left(Q_{a e o}\right)\end{array}$ & $\begin{array}{c}\text { (students' estimation }+ \text { PTS estimation) } \\
/ 2\end{array}$ \\
\hline \multirow{7}{*}{2 Coefficient of PTS quality $\left(\mathrm{Q}_{\mathrm{pts}}\right)$} & 2.1 Coefficient of PTS competence $\left(\mathrm{Q}_{\text {comp }}\right)$ & $\begin{array}{c}\mathrm{Q}_{\mathrm{pts}}=\left(\mathrm{Q}_{\text {comp }}+\mathrm{Q}_{\mathrm{pk}}+\mathrm{Q}_{\text {cont }}+\mathrm{Q}_{\mathrm{ob}}+\mathrm{Q}_{\mathrm{inn}}+\right. \\
\left.\mathrm{Q}_{\mathrm{std}}+\mathrm{Q}_{\text {qual }}\right) / 7 \\
\text { (students' estimation }+ \text { PTS estimation) } \\
/ 2\end{array}$ \\
\hline & $\begin{array}{l}2.2 \text { Coefficient of perceptibility of } \\
\text { knowledge, transmitted by teachers }\left(\mathrm{Q}_{\mathrm{pk}}\right)\end{array}$ & $\begin{array}{c}\text { (students' estimation }+ \text { PTS estimation) } \\
/ 2\end{array}$ \\
\hline & $\begin{array}{l}2.3 \text { Coefficient of ability to find contact } \\
\text { with audience }\left(\mathrm{Q}_{\text {cont }}\right)\end{array}$ & $\begin{array}{c}\text { (students' estimation + PTS estimation) } \\
/ 2\end{array}$ \\
\hline & $\begin{array}{l}\text { 2.4 Coefficient of ability to estimate } \\
\text { knowledge, skills and habits of student } \\
\text { objectively }\left(\mathrm{Q}_{\mathrm{ob}}\right)\end{array}$ & $\begin{array}{c}\text { (students' estimation }+ \text { PTS estimation) } \\
1 / 2\end{array}$ \\
\hline & $\begin{array}{l}2.5 \text { Coefficient of ability to apply } \\
\text { innovative approaches to study }\left(Q_{\text {inn }}\right)\end{array}$ & $\begin{array}{c}\text { (students' estimation }+ \text { PTS estimation) } \\
/ 2\end{array}$ \\
\hline & $\begin{array}{l}\text { 2.6 Coefficient of steady nature (on the } \\
\text { department, speciality training, higher } \\
\text { educational establishment })\left(\mathrm{Q}_{\text {std }}\right)\end{array}$ & $\begin{array}{c}\text { relation of actual steady nature to the } \\
\text { standard }(60 \%) \text {; at steady nature }>60 \% \\
\text { is taken as } 1\end{array}$ \\
\hline & $\begin{array}{l}\text { 2.7 Coefficient of average annual per cent } \\
\text { of qualification advancement for the last } 5 \\
\text { years }\left(\mathrm{Q}_{\text {qual }}\right)\end{array}$ & $\begin{array}{c}\text { relation to the actual per cent of } \\
\text { qualification advancement to the } \\
\text { standard }(20 \%) \text {; at indicator }>20 \% \text { is } \\
\text { taken as } 1\end{array}$ \\
\hline \multirow{2}{*}{$\begin{array}{l}\text { Integral indicator of quality estimation of } \\
\text { the integrative intellectual resource of the } \\
\text { higher educational establishment }\left(Q_{\text {iir }}\right) \\
\end{array}$} & \multirow[b]{2}{*}{ Local indicators } & Calculation way of indicators \\
\hline & & $\mathrm{Q}_{\text {iir }}=\left(\mathrm{Q}_{\mathrm{st}}+\mathrm{Q}_{\mathrm{pts}}+\mathrm{Q}_{\text {int }}\right) / 3$ \\
\hline $\begin{array}{c}3 \text { Coefficient of interaction quality of } \\
\text { teachers with students in the process of } \\
\text { study }\left(\mathrm{Q}_{\text {int }}\right)\end{array}$ & & $\begin{array}{c}\text { (students' estimation }+ \text { PTS estimation) } \\
/ 2\end{array}$ \\
\hline
\end{tabular}


The first two coefficients are intermediary integral indicators, also calculated as the average arithmetic local indicators (coefficients) of second level. In its turn, the local indicators are fluctuated in the interval from 0 to 1 and can be determined by two ways:

- As relation of actual indicator to the standard one - it concerns already known indicators, for which the standards are determined by the bodies of management of the country education, for example, in the Russian Federation this is the per cent of steady characteristic and per cent of qualification advancement;

- As the average arithmetic coefficient, obtained in the course of questionnaires of the interested parties (students and PTS).

For calculation of such coefficient the results of questionnaires on the corresponding issues are processed. At that the questionnaire forms suppose possibility of estimation of one or other characteristic of respondents on 5-point scale: from "1" (very bad) to "5" (excellent). According to the results of processing of questionnaire forms the average point for answers on each question is determined and then the coefficient of correspondence of the actual required estimation (maximally possible) is calculated.

According to the required qualitative indicators the maximal possible point is " 5 ", and minimally possible point " 1 ". However, for the correct calculation of the coefficient, it is necessary that minimal possible values made 0 , consequently, the transit of point evaluations in the scale "from 0 to 4 " is required. Then, point " 4 " becomes maximally possible point. So the calculation of compliance coefficients for qualitative indicators is conducted according to the formula:

$$
\mathrm{Q}_{\mathrm{i}}=\left(\mathrm{P}_{\mathrm{a}}-1\right) / 4
$$

Where:

$\mathrm{Q}_{\mathrm{i}}$ - coefficient of conformity;

$\mathrm{P}_{\mathrm{a}}$ - actual obtained average point according to the results of questionnaire conduction.

The estimation of intellectual resource of higher education establishment is indispensable part of integral system of quality evaluation of providing the educational service, so they offer respondents to include the corresponding issues into the general questionnaire forms of students' survey and PTS, developed on the special forms (the questionnaire form of PTS survey developed by us is shown in Appendix A).

Thus, for approbation and calculation of the offered indicators the necessity in additional study appeared in the form of questionnaire of the interested parties. So, we conducted:

- The survey of students of the largest higher educational establishments of Primorsk Territory of the Russian Federation (VSUES, FESU, FESTU and TSEU), totally 600 students were questioned;

- The survey of PTS of the same higher educational establishments; in general complexity, 150 teachers were questioned.

The results of calculation of the integral quality estimation of the intellectual resource of higher educational establishments of Primorsk Territory, in accordance with the conducted study, as it is shown in table 2.

The results of the conducted study show that the integral indicators of quality estimation of intellectual resource of the higher educational establishments of Primorsk Territory of the Russian Federation insufficiently vary according to the different higher educational establishments. It tells about similarity of the problems, which evaluated educational establishments face. The most vulnerable party of the intellectual resource is the quality of students, including the ability to learn the material, learning completeness, and desire to obtain knowledge, skills and habits. The considerable problems also exists in the sphere of PTS quality, including competence, ability to find contact with the audience, objectively evaluation of knowledge, skills and habits of students. There are the most problematic aspects of state of intellectual resource of the higher educational establishment, according to which it is necessary to take decisions and on the level of educational establishments, and on the level of education management bodies.

However, the problem is not exhausted with the estimation of quality of providing the educational service that includes the evaluation of the intellectual resource. It is no less important to estimate the effect obtained from education, actual result of providing the educational service. So the methods of estimation of such results, analogous methods of evaluation of the quality of intellectual resource was developed and tested.

The estimation of the effectiveness of providing the educational services in the studied higher educational establishments was conducted. The official indicators of higher educational establishment activity serve as the information basis, and also the qualitative indicators. There were revealed in the course of survey conduction of 
600 students, 150 teachers, 200 graduating students (VSUES, FESU, FESTU and TSEU) and 100 managers of enterprises and organizations, in which 216 school-leavers of these higher educational establishments work during last 3 years.

Table 2. Integral indicators of evaluation of the intellectual resource of higher educational establishments of Primorsk Territory of the Russian Federation

\begin{tabular}{|c|c|c|c|c|c|}
\hline Higher educational establishments & VSUES & FESU & FESTU & TSEU & $\begin{array}{c}\text { Wholly on the examined } \\
\text { higher educational } \\
\text { establishments }\end{array}$ \\
\hline $\begin{array}{l}\text { Integral indicators of the quality evaluation of the } \\
\text { integrative resource of providing the educational } \\
\text { services }\end{array}$ & 0.7226 & 0.716 & 0.717 & 0.7348 & 0.724 \\
\hline 1. Coefficient of students' quality & 0.6922 & 0.6789 & 0.7005 & 0.681 & 0.6874 \\
\hline 2. Coefficients of PTS quality & 0.7955 & 0.8039 & 0.822 & 0.7575 & 0.7947 \\
\hline $\begin{array}{l}\text { 3. Coefficient of interaction quality of teachers } \\
\text { with students in the process of communication }\end{array}$ & 0.7413 & 0.7275 & 0.7288 & 0.7425 & 0.7338 \\
\hline
\end{tabular}

We consider especially important the evaluation of the qualities of graduating students for employer, as namely on it the possibility of labour employment and conditions of labour activity of the students in the perspective. The results of employers' survey are represented in Appendix B.

The resulted data show that employers on the whole well estimate the general level of professional training of the graduating students. However, they relatively poor characterize their initiative in work, speed of implementation of professional tasks, potential willingness of young specialists to execute the types of works new for them, that in modern terms is the important shortage. Moreover, it is especially important that the employers critically estimate the prospects of employment of graduating students of last years. It means that at the leaders of enterprises have not high opinions about ability of graduating students of higher educational establishments in the future to become valuable replacement to the present skillful specialists that they doubt in their ability to apply the knowledge obtained in practice successfully. Consequently, it is necessary to expose and remove lacks of educational process in the higher educational establishments, increase the degree of integration of educational establishments with enterprises and scientific-research organizations, implement the innovative methods of teaching, and pay attention to ability of teaching staff effectively to apply these methods.

Based upon detected quantitative and qualitative local indicators in the higher educational establishments, their transform into the coefficients of compliance and offered model of calculation, the final integral indicators of the effectiveness of providing educational services to the required level on each of the studied higher educational establishments and whole set of higher educational establishments were determined (Table 3 ).

Table 3. Integral indicators of effectiveness of providing educational services and factors, determining it

\begin{tabular}{|c|c|c|c|c|c|}
\hline $\begin{array}{l}\text { Factors effecting } \\
\text { on the integral indicator }\end{array}$ & VSUES & FESU & FESTU & TSEU & $\begin{array}{l}\text { Wholly on the } \\
\text { studied higher } \\
\text { educational } \\
\text { establishments }\end{array}$ \\
\hline $\begin{array}{l}\text { 1. Coefficient of the state attestation } \\
\text { results }\end{array}$ & 0.7482 & 0.7309 & 0.7675 & 0.7765 & 0.7583 \\
\hline $\begin{array}{l}\text { 2. Coefficient of possessing the } \\
\text { necessary competences by the graduating } \\
\text { students }\end{array}$ & 0.7249 & 0.7045 & 0.7192 & 0.7243 & 0.7172 \\
\hline $\begin{array}{l}\text { 3. Coefficient of prestige of the diploma } \\
\text { on the speciality obtained }\end{array}$ & 0.728 & 0.7108 & 0.7238 & 0.727 & 0.721 \\
\hline $\begin{array}{l}\text { 4. Coefficient of labour employment of } \\
\text { the graduating students }\end{array}$ & 0.7393 & 0.6334 & 0.6277 & 0.7775 & 0.7541 \\
\hline $\begin{array}{l}\text { 5. Coefficients of involvement of } \\
\text { knowledge, skills and habits in } \\
\text { professional activity of the graduating } \\
\text { students }\end{array}$ & 0.6495 & 0.6455 & 0.6545 & 0.673 & 0.6535 \\
\hline $\begin{array}{l}\text { 6. Coefficient of the professional } \\
\text { characteristics of the graduating students }\end{array}$ & 0.6894 & 0.7773 & 0.6869 & 0.6908 & 0.6857 \\
\hline $\begin{array}{l}\text { The integral indicator of the } \\
\text { effectiveness of providing the } \\
\text { educational services }\end{array}$ & 0.7124 & 0.6981 & 0.6919 & 0.7283 & 0.7147 \\
\hline
\end{tabular}


The data of Table 3 show that the most problematic characteristics of effectiveness of providing the educational services of the studied higher educational establishments are:

- Involvements of knowledge, skills and habits in the professional activity of the graduating students;

- Professional characteristics of graduating students.

The worst coefficients were obtained on these two indicators.

Consequently, namely in this sphere most important for the graduating students - ability to employ on the work on the beneficial conditions and effectively apply the knowledge obtained in the course of study in practice - the most evident shortages are marked.

So it is necessary to improve both organization and estimation of providing the educational services, including the intellectual resource state of the higher educational establishment, as its most important constituent. The offered methods provide evaluation not only integral indicator of the intellectual resource state, but also local indicators, i.e. different aspects - PTS competence, its ability to arrange contact with the audience, ability of students to perceive material, their activity in the process of study and etc. The methods are applied for estimation of the intellectual resource of the higher educational establishments of different countries, as at all peculiarities of national systems of higher professional education, it faces the similar problems.

\section{Results}

Thus, the educational management bodies of different states, the higher educational establishments and their separate subdivisions, up to the concrete teachers, can find and purposefully to correct "narrow places", weal parties both the students and PTS. This will promote to the increase of quality and effectiveness of providing the educational services that finally positively reflect on the state of economy and society.

\section{References}

Avramova, N. A. (2009). Pre-profile training. Profile teaching. Professional self-determination. Retrieved from http://teacherpsy.21309.edusite.ru/DswMedia/predprofil-noeobuchenie.ppt.

Criteria for Higher-Quality Assessment. (2013). Stanford: Stanford Center for Opportunity Policy in Education; Los Angeles: Center for Research on Student Standards and Testing, University of California; Chicago: Learning Sciences Research Institute, University of Illinois.

Livanov, D., \& Volkov, A. (2012). Stake on the new content. Vedomosti, 3, 9-12.

Mogilchak, E. L. (2009). Higher education and market relations: sociological aspect of interaction. Izvestiya of Ural State University, 12(64), 210-218.

Nevinskii, V. V. (2010). Scientific-innovative activity - new turns. Za nauku!, 4, 1.

Osovetskaya, N. Ya. (2012). Estimation of the demand in masters for provision of the competitive ability in Russia. Retrieved from http://www.hse.ru/data/070/761/1235/Osovetskaya.doc

Podolskii, S. V. (2010). Resource provision of the educational process in higher educational establishments. Vestnik of Pacific Ocean State Economic University, 4, 78-87.

Professional education in Primorsk Territory. (2010). Vladivostok: Primorskstat.

Rappoport, I. K. (2011). Medical survey and therapeutical professional consulting of the students. Retrieved from http://edu.resobr.ru/archive/year/articles/1145/

Results of USE were summarized in Primor'e. Retrieved from http://www.vladtime.ru/2011/07/21/v-primorepodvedeny-rezultaty-egye.html

Results of USE were summarized in Vladivostok: school-children of Primor'e began to love physics more and know English better. Retrieved from http://www.newsvl.ru/vlad/2011/06/27/88988/

Safonova, K. I., \& Podolskii, S. V. (2012). Requirements to the integrative intellectual resource of higher educational establishment as the factor of effectiveness increase of the educational process. Najnovite nauchni postizhenia. Proceedings of VIII international scientific-practical conference (March 17-25, 2012), Vol. 13, Pedagogical sciences. Sofia: Bial GRAD-BG OOD (pp. 48-54).

Safonova, K. I., \& Chmyr', Yu. (2009). Estimation of the state of qualification advancement of the teaching and scientific staff as a factor of staff potential growth in the higher educational establishments on the SRI of Primorsk Territory. Regional economy: theory and practice, 27(120), 70-76.

Zimniaya, I. A. (2008). Integrative approach to estimation of the single social-professional competence of the 
graduating students of higher educational establishments. Higher education today, 5, 14-19.

\title{
Appendix A
}

\section{Questionnaire form "The survey of professor-teaching staff of the higher educational establishments of Primorsk Territory"}

\author{
Dear teachers!
}

Within the project framework of studying the state of educational services in higher educational establishments in Primorsk Territory, the survey of teachers is conducted. The results of study will serve exclusively to the scientific purposes. The data obtained from you will remain anonymous. The survey completely bears voluntary character, but the more people will be asked, the more reliable the results of study will be. We'll ask you to read issues attentively and express your opinion. Any opinion is important for us, and we are interested in your sincerity!

1. Name of higher educational establishment, which you work for:

2. Speciality of students, you teach

3. Disciplines taught

4. Your work experience in these disciplines

5. Estimate according to 5-point scale, how much the following characteristics of the educational service satisfy you (from 1 - absolutely don't satisfy to 5 - completely satisfy):

5.1 explanation of the material by teachers;

5.2 ability of students to perception of the knowledge rendered;

5.3 completeness of mastering the educational material by the students;

5.4 attentiveness degree, paid to the students by the teachers;

5.5 presence of individual approach to each student;

5.6 interest of students to the educational process;

5.7 presence of necessary working atmosphere on the classes;

5.8 time, spent by the students on the educational process;

5.9 share of tasks, which are given by the students on the independent work;

5.10 degree of psychological satisfaction by the process of education on the part of students;

5.11 provision of auditorium classes with necessary equipment and office automation;

5.12 provision of auditorium classes with information technologies;

5.13 possibility of discussion organization and expression of the own point of view;

5.14 degree of practical significance of the educational material;

5.15 objectiveness of estimation of the knowledge, skills and habits of the students;

5.16 results of the independent works of students;

5.17 competence of the profession-teaching staff;

5.18 requirements of teachers to the students, their compliance to the level of teaching;

5.19 new forms of educational process organization;

5.20 level of educational programmes on profile disciplines;

5.21 level of educational programmes on general educational disciplines;

5.22 renewal of educational programmes on the profile disciplines;

5.23 renewal of educational programmes on the general educational disciplines;

5.24 sufficiency of the educational literature on profile disciplines;

5.25 sufficiency of the educational literature on the general educational disciplines;

5.26 level of educational literature on the profile disciplines;

5.27 level of the educational literature on generally educational disciplines;

5.28 renewal of educational literature on the profile disciplines;

5.29 renewal of educational literature on the generally educational disciplines; 
5.30 sufficiency of the methodical specifications on the profile disciplines;

5.31 sufficiency of the methodical specifications on the general educational disciplines;

5.32 level of the methodical specifications on the profile disciplines;

5.33 level of the methodical specifications on the generally educational disciplines;

5.34 renewal of the methodical specifications on the profile disciplines;

5.35 renewal of the methodical specifications on the general educational disciplines;

5.36 level of execution of course-works by the students;

5.37 level of execution of graduation thesis by the students;

5.38 level of execution of other scientific works by the students (including theses of the scientific conferences, scientific articles, participation in the scientific and production projects of the higher educational establishments);

5.39 objectiveness of the estimation of the course-works;

5.40 objectiveness of the estimation of graduation theses;

5.41 objectiveness of the estimation of other scientific works of students;

5.42 level of professional experience, obtained by the students in the course of production practice;

5.43 level of execution of reports about production practice by the students;

5.44 objectiveness of the estimation of production practice reports;

5.45 level of professional experience, obtained by the students in the course of prediploma practice;

5.46 level of execution of the prediploma practice reports;

5.47 objective estimation of prediploma practice reports;

5.48 quality of innovation projects, made in the course of educational process for the last 3 years;

5.49 level of innovative scientific projects, made in the course of educational process;

5.50 level of production innovation activity of the higher educational establishment;

5.51 state of the material-technical provision of the educational process (equipment, office automation, and etc.), including its:

5.51.1 sufficiency;

5.51.2 functionality;

5.51 .3 reliability;

5.51 .4 convenience of usage in the educational process;

5.52 state of information provision of the educational process (computer programme, other information technologies), including its:

5.52.1 sufficiency;

5.52.2 functionality;

5.52 .3 reliability;

5.52.4 convenience of usage in the educational process;

5.53 state of educational process management, including:

5.53.1 management of higher educational establishment on the whole;

5.53.2 activity coordination of subdivisions, including the departments;

5.53.3 usage of financial resources by the higher educational establishment;

5.53.4 management on the level of direction (speciality);

5.53.5 management on the level of department;

5.54 motivation of the choice of higher educational establishment by the university entrants;

5.55 motivation of the choice of speciality by the university entrants;

5.56 ability of students to learn the material;

5.57 desire of students to obtain knowledge, skills and habits;

5.58 disposition of students to protection of the independent point of view;

5.59 disposition of students to the scientific-research work;

5.60 progress of students;

5.61 objectiveness of the progress estimation; 
5.62 perception of knowledge, rendered by the teachers;

5.63 ability of teachers to find contact with the audience;

5.64 ability of teachers to apply innovation approaches to study;

5.65 level of interaction of teachers with students in the process of study;

5.66 level of mastering the professional competences by the graduating students;

5.67 level of mastering the general cultural competences by the graduating students;

5.68 prestige of diploma on the speciality obtained;

5.69 financial accessibility of the fee-paying educational service for the majority of students;

5.70 sufficiency of funds, obtained from provision of the fee-paying educational services for higher educational establishments;

5.71 sufficiency of budget financing for provision of high level of services provided;

5.72 sufficiency of funds, obtained owing to the additional scientific and production activity, for development and improvement of the service by the higher educational establishment;

5.73 share of students, who study on the fee-paying basis;

5.74 effect of the fee-paying study on its character and its results.

6 . Your notes and offers (not obligatory for filling)

\section{Thank you for participation in survey!}

\section{Appendix B}

\section{Results of employers' survey}

Quality of works

\begin{tabular}{cccccccc}
\hline Points & 1 & 2 & 3 & 4 & 5 & Average point & Coefficient of conformity \\
\hline $\begin{array}{c}\text { Totally evaluated graduating students } \\
\text { Including on all higher educational }\end{array}$ & 3 & 18 & 49 & 81 & 65 & 3.87 & 0.7175 \\
$\begin{array}{c}\text { establishments: } \\
\text { VSUES }\end{array}$ & 1 & 4 & 13 & 21 & 17 & 3.88 & \\
FESU & 0 & 7 & 16 & 25 & 20 & 3.85 & 0.72 \\
FESTU & 1 & 4 & 10 & 17 & 13 & 3.82 & 0.7125 \\
TSEU & 1 & 3 & 10 & 18 & 15 & 3.92 & 0.73 \\
\hline
\end{tabular}

Quickness rate of works executed

\begin{tabular}{|c|c|c|c|c|c|c|c|}
\hline Points & 1 & 2 & 3 & 4 & 5 & Average point & Coefficient of conformity \\
\hline $\begin{array}{l}\text { Totally evaluated graduating students } \\
\text { Including on all higher educational } \\
\text { establishments: }\end{array}$ & 7 & 24 & 63 & 69 & 53 & 3.63 & 0.6575 \\
\hline VSUES & 2 & 7 & 15 & 17 & 15 & 3.64 & 0.66 \\
\hline FESU & 2 & 9 & 19 & 22 & 16 & 3.6 & 0.65 \\
\hline FESTU & 0 & 5 & 15 & 14 & 11 & 3.69 & 0.6725 \\
\hline TSEU & 3 & 3 & 14 & 16 & 11 & 3.62 & 0.655 \\
\hline \multicolumn{8}{|c|}{ Initiative rate of workers } \\
\hline Points & 1 & 2 & 3 & 4 & 5 & Average point & Coefficient of conformity \\
\hline $\begin{array}{l}\text { Totally evaluated graduating students } \\
\text { Including on all higher educational } \\
\text { establishments: }\end{array}$ & 10 & 29 & 68 & 70 & 39 & 3.46 & 0.615 \\
\hline VSUES & 2 & 8 & 18 & 18 & 10 & 3.46 & 0.615 \\
\hline FESU & 4 & 10 & 22 & 20 & 12 & 3.38 & 0.595 \\
\hline FESTU & 2 & 6 & 12 & 16 & 9 & 3.53 & 0.6325 \\
\hline TSEU & 2 & 5 & 16 & 16 & 8 & 3.49 & 0.6225 \\
\hline
\end{tabular}


Level of general professional training

\begin{tabular}{cccccccc}
\hline Points & 1 & 2 & 3 & 4 & 5 & Average point & Coefficient of conformity \\
\hline $\begin{array}{c}\text { Totally evaluated graduating students } \\
\text { Including on all higher educational }\end{array}$ & 4 & 9 & 45 & 72 & 86 & 4.05 & 0.7625 \\
$\begin{array}{c}\text { establishments: } \\
\text { VSUES }\end{array}$ & 2 & 3 & 11 & 18 & 22 & 3.98 & \\
FESU & 0 & 4 & 17 & 22 & 25 & 4 & 0.745 \\
FESTU & 2 & 1 & 9 & 15 & 18 & 4.02 & 0.75 \\
TSEU & 0 & 1 & 8 & 17 & 21 & 4.23 & 0.755 \\
\end{tabular}

Potential readiness to execution of the new types of work

\begin{tabular}{cccccccc}
\hline Points & 1 & 2 & 3 & 4 & 5 & Average point & Coefficient of conformity \\
\hline $\begin{array}{c}\text { Totally evaluated graduating students } \\
\text { Including on all higher educational }\end{array}$ & 7 & 16 & 62 & 81 & 50 & 3.7 & 0.675 \\
$\begin{array}{c}\text { establishments: } \\
\text { VSUES }\end{array}$ & 1 & 4 & 16 & 21 & 14 & 3.77 & \\
FESU & 3 & 6 & 20 & 24 & 15 & 3.62 & 0.6925 \\
FESTU & 1 & 3 & 12 & 18 & 11 & 3.78 & 0.655 \\
TSEU & 2 & 3 & 14 & 18 & 10 & 3.66 & 0.695 \\
\hline
\end{tabular}

Prestige of diploma on the speciality received

\begin{tabular}{cccccccc}
\hline Point & 1 & 2 & 3 & 4 & 5 & Average point & Coefficient of conformity \\
\hline Totally evaluated graduating students & 3 & 8 & 27 & 30 & 32 & 3.8 & 0.7 \\
\hline
\end{tabular}

Perspectives of labour employment of the graduating students on speciality

\begin{tabular}{llllllll}
\hline Points & 1 & 2 & 3 & 4 & 5 & Average point & Coefficient of conformity \\
\hline Totally evaluated graduating students & 3 & 12 & 28 & 39 & 18 & 3.57 & 0.6425 \\
\hline
\end{tabular}

Degree of involvement of the knowledge, skills and habits in the professional activity obtained in the course of study

\begin{tabular}{cccccccc}
\hline Points & 1 & 2 & 3 & 4 & 5 & Average point & Coefficient of conformity \\
\hline Totally evaluated graduating students & 1 & 6 & 17 & 42 & 34 & 4.02 & 0.755 \\
\hline
\end{tabular}

\section{Copyrights}

Copyright for this article is retained by the author(s), with first publication rights granted to the journal.

This is an open-access article distributed under the terms and conditions of the Creative Commons Attribution license (http://creativecommons.org/licenses/by/3.0/). 